\title{
Do Same-Sex and Straight Weddings Aspire To the Fairytale? Women's Conformity and Resistance to Traditional Weddings
}

\author{
Tina Fetner, McMaster University \\ and \\ Melanie Heath, McMaster University*
}

* This article is equally co-authored.

Contact

Tina Fetner and Melanie Heath, Department of Sociology, McMaster University, I 280 Main

Street West, Hamilton, Ontario, Canada L8S 4M4. Email: tina.fetner@mcmaster.ca and mheath@mcmaster.ca.

\section{Acknowledgements}

The authors want to thank co-editor James Elliott and two anonymous reviewers for their incredibly helpful comments and suggestions. We also want to thank Jessica Braimoh and NikkiMarie Brown, Ph.D. candidates at McMaster Sociology, for their research assistance on this project. Finally, we want to thank our research participants for their time and their thoughtful responses. This research was funded as a SSHRC Standard Research Grant, "The Changing Face of Matrimony in Canada: A Study of Same-Sex Marriage in Three Ontario Cities," Adam Isaiah Green, University of Toronto, Principal Investigator, Barry Adam, University of Windsor, and Tina Fetner, McMaster University, Co-Investigators.

Published as:

Tina Fetner and Melanie Heath. 2016. "Do Same-Sex and Straight Weddings Aspire To the Fairytale? Women's Conformity and Resistance to Traditional Weddings." Sociological Perspectives 54:721-742. 
I want to say that I was challenged by my friends about the idea of legal marriage,... about reproducing [the institution], about taking on a heterosexual form for the relationship. But I think, there were a couple things that pushed me forward, and one of them was the fact that it hadn't been available to us. I think had it been out there the whole time for us all along, perhaps we wouldn't have done it, or I wouldn't have done the legal thing. But I felt this sort of social justice equity thing, and that was probably motivating me.

Catherine, 5 I-year-old, White, Same-Sex Marriage

The above quote illuminates the tensions that arise for many same-sex couples for whom legally recognized marriage is now an option. Catherine recounted the challenge she faced from her friends over the idea that her decision to marry might reproduce the heteronormativity that has historically stigmatized and repressed lesbian and gay intimacies. Ultimately, she described her choice as a social justice issue. Her analysis demonstrates an awareness of what Chrys Ingraham (2008) calls the "heterosexual imaginary," a belief system that depends on the invisible power of heterosexuality to organize and structure gender hierarchies - for example, to define the expectations of what it means to be a husband and wife-along the lines of race, class, and sexuality. Catherine described her reasoning in coming to terms with the critique of marriage, displaying a form of deliberation that - given the heterosexual imaginary-many heterosexual couples may not feel compelled to undertake.

In her influential book, White Weddings, Ingraham (2008) provides a media analysis to uncover the dark side of the wedding industry that markets an idealized image of the bride in a formal white gown, and the production of the wedding with attendants, rings, and a reception at an average cost of just under $\$ 30,000$. She argues that the image of the white wedding has become such a powerful symbol of heteronormativity and traditional gender arrangements that it obscures other possibilities of understanding commitments and relationships. However, scholars of same-sex weddings emphasize the resistance to heteronormativity that is performed 
through these ceremonies (Kimport 2012; Taylor, et al. 2009). Given the recent emergence of legal recognition of same-sex marriage in some jurisdictions, we reconsider women's conformity and resistance to traditional, "white wedding" ceremonies. Do women in straight weddings and same-sex weddings create similarly traditional ceremonies? Are they subject to a similar set of social pressures to have their weddings appear conventional? What are their understandings of the meanings of wedding ceremonies, and how deeply do they consider these meanings?

To answer these questions, we draw on in-depth interviews with forty-six recently married women: twenty-seven in straight marriages and nineteen in same-sex marriages. Interviews were conducted in Ontario, Canada, where same-sex marriage has been legal since 2003. We find that all the women in our sample, whether in straight or same-sex marriages, were aware of the demands imposed by the conventions of the traditional wedding ritual. However, there were substantial differences in the ways our participants engaged with them. Many of our straight-marriage participants either embraced the traditional wedding ceremony or acquiesced to social pressures to conform. While some women in same-sex marriages also embraced a traditional wedding ceremony, most did not. Regardless of the type of ceremony, participants in same-sex weddings thought deeply about their choices of wedding style and what it would communicate about themselves to their families and friends. Our participants also included a group of women, in both straight and same-sex marriages, who offered a critique of the traditional wedding ceremony as overly costly and wasteful. We discuss the implications of these findings for scholarly research on weddings, gender, and heteronormativity. 


\section{ROMANCING THE WEDDING IMAGINARY: HETERONORMATIVITY, GENDER, AND CONSUMERISM}

The conventional wedding is a window into the heteronormative structure of society, operating as a "concentrated site for the operation and reproduction of organized heterosexuality" (Ingraham 2008:3). Scholarship on the critical study of heterosexuality, which emerged in the 1990s, has shed light on the institutional aspects of weddings and marriage as a central component in maintaining heteronormativity. This theoretical focus emerged out of radical lesbian feminist critiques of heterosexuality as a patriarchal institution that privileges marriage as the invisible core of natural and desirable sexuality, and places homosexuality on the periphery as perverse and unnatural (Roseneil 2002; Rubin 1984). Legal marriage has consequently been a central mechanism used by the state to regulate institutionalized heterosexuality and that of the "natural" (white, middle-class) family (Heath 2009).

Research on hegemonic meanings of the conventional wedding has predominantly analyzed media and consumer aspects of the bridal industry. In White Weddings, Chrys Ingraham (2008) examined popular culture, such as bridal magazines, toys, and wedding announcements, to illuminate the power of white weddings that are constituted by heteronormativity, dominant gender norms, and consumerism, and that perpetuate the romance and fairytale-like narrative of the beautiful bride and handsome groom who are generally white and prosperous. Her analysis sheds light on the "wedding industry complex," a global, capitalist phenomenon that targets the upper income brackets, promotes whiteness as universal, and encourages conspicuous consumption even for those who cannot afford it. She identified the "heterosexual imaginary" as a belief system that naturalizes gender as a biological necessity, and solidifies the 
idea that there are fundamental, biological differences that bring men and women together in heterosexual union.

Otnes and Pleck (2003) also analyzed popular culture to uncover how the wedding industry celebrates the love of consumption, pushing brides to consume goods that reflect an obsession with the culture of love. They argue that weddings help to realize the Cinderella myth of feminine upward mobility that is represented through a lavish ritual. Thus, consumer culture packages the ideal wedding — with the heterosexual couple at center-to perpetuate the myth that any bride in white can be a symbolic princess. Likewise, Tombaugh (2009) conducted a textual analysis of wedding advice columns to demonstrate how these represented women's subordinated status and confirmed heterosexuality as the unquestioned norm.

While analysis of popular culture has uncovered the processes that perpetuate the equation of traditional weddings, heteronormativity and conservative gender norms, this line of research is not able to speak to how these norms impact the individuals who choose to wed. A few empirical studies have considered how heterosexual couples view conventional wedding ceremonies. Currie (1993), for example, conducted in-depth interviews in Canada to illustrate how tradition influenced couples to choose wedding themes that represented conservative meanings that were separate from those that they assigned to marital relations. Boden (2003) combined media analysis with qualitative interviews to find that the wedding culture turned ordinary female consumers into "superbrides" who emulate the ideals of white weddings that become linked to patterns of consumption. Recent research has also uncovered the ways that conservative gender norms continue to influence wedding practices. Humble, Zvonkovic, and Walker (2008) conducted interviews with 2 I newly married heterosexual couples to find that the unequal gendered division of labor in the wedding planning process portended future unequal gender relations. Also underscoring the endurance of conservative gender norms, 
Baker and Elizabeth (2013) found that many heterosexual women in cohabiting relationships wanted to marry but typically waited for their male partner to propose.

While research demonstrates that weddings continue to shape traditional ideas about gender, recent empirical research has also complicated the idea of a wedding industry that simply dictates the terms of consumption. Blakely (2008) examined how busy, privileged career women outsourced their wedding planning, relying on others to make their day special. Her qualitative analysis of the wedding planning industry showed that wedding planners drew on the language of liberal feminism to convince career women that they can, in fact, "have it all," giving brides more latitude to resist tradition. The research of Humble (2009) also uncovered complexities in the ways that remarrying couples engaged the wedding industry, noting that these couples were freer to plan the weddings they wanted. These findings suggest that traditional weddings are powerful influences in shaping individual behavior but point to the need for more empirical research on how brides conform to or resist prevailing wedding rituals.

The growing legal possibility for same-sex couples to marry presents another perspective on the normalizing aspects of the conventional wedding. A number of scholars have argued that the advent of legalized same-sex marriage will challenge and perhaps abolish heteronormativity (e.g., Eskridge 1996; Kitzinger and Wilkinson 2004; Stoddard 1992; Wolfson 2004). Other queer and feminist theorists argue that marriage among lesbians and gay men will result in homonormativity, or a "politics that does not contest dominant heteronormative assumptions and institutions, but upholds and sustains them, while promising ... a privatized, depoliticized gay culture anchored in domesticity and consumption" (Duggan 2003: 50). This line of reasoning views the heterosexual imaginary as able to extend to lesbians and gay men who marry (Jowett and Peel 2010; Kandaswamy 2008; Valverde 2006). These debates move 
beyond academia, into the lesbian and gay movement as well as the larger LGBTQ community (Bernstein and Taylor 2013; Green 20I3).

Studies of lesbian and gay relationships and marriages offer a complex picture of marriage's normalizing effects. Same-sex and different-sex couples often share similar pathways in their decisions to formalize their relationships (Baker and Elizabeth 2012). Married respondents in California and Canada expressed a renewed sense of security after marrying, including increased feelings of commitment in their relationship and of being protected by the larger society (Macintosh, Reissing, and Andruff 2010; Shulman, Gotta, and Green 20I2). However, nascent research on same-sex married couples also challenges the idea that lesbians and gay men necessarily embrace traditional norms of marriage. Green (2010), for example, found that same-sex couples in Canada adopted a variety of nontraditional norms that may destabilize conventional marital patterns. The act of holding a commitment ceremony and/or marrying can also be a form of activism that both reinforces and disrupts heteronormativity (Hull 2006; Kimport 20 I3; Taylor, et al. 2009). Likewise, Kimport (2012) analyzed wedding photographs from the 2004 same-sex weddings in San Francisco, showing how wedding normativity among lesbian couples presented a challenge to symbolic assumptions about normative gender and sexuality.

Current research suggests that lesbians and gay men actively engage the issue of homonormativity in their decision-making process on whether to publicly celebrate their relationship. Lewin (1998) conducted ethnographic research in the United States on commitment ceremonies and found vigorous resistance among some same-sex couples to heteronormative ideals; however, others desired the "normal" white wedding. Shipman and Smart (2007:20) found in their interviews with same-sex couples in Britain that many felt ambivalent about participating in a civil partnership due to worries over homonormativity; 
however, they ultimately decided that the benefits of receiving recognition and legal protection "outweighed the fear of being co-opted into a heteronormative or patriarchal institution" (see also Schecter et al. 2008 for similar findings in the United States). Likewise, a study of mid- to later-life same-sex couples who married in Canada found that these couples planned their weddings more deliberately due to lifetime experiences of homophobia and/or heterosexism (Humble 2013). A number of same-sex couples in Britain chose "minimalist weddings," because they wanted to ensure that their civil partnerships did not mimic the rituals of a heterosexual wedding (Rolfe and Peel 20I I; Smart 2008).

In sum, the literature on weddings and heteronormativity speaks to the continuing power of the heterosexual imaginary and its implications for conspicuous consumption of lavish weddings. Yet, it also suggests openings for couples to question and/or resist the trappings of white weddings, especially among same-sex partners. We contribute to this growing body of research by offering a systematic and comparative study of how individuals make decisions about their weddings in the context of the consumerist turn that interpellates both heterosexual and same-sex couples in countries with legalized same-sex marriage. What are the differences between straight and same-sex couples in their wedding choices? Because the wedding industry specifically targets women with a vision of the "Cinderella" wedding, we focus our research on women in same-sex and straight marriages. Our analysis identifies the ways that many heterosexual women non-reflexively or acquiescently adopt the normative standards of the conventional wedding. Importantly, we also find a large number of resisters in both heterosexual and same-sex marriages who engage a cultural critique of tradition and consumerism that allows them to imbue their ceremonies with counter-hegemonic meanings of frugality, religion, family and commitment. 


\section{DATA AND METHODS}

For this project, we analyzed semi-structured, in-depth interviews of women who are legally married and had participated in a wedding ceremony. Participants were recruited using a comparative sampling frame targeting one group of women married to men, and another group of women married to women. These interviews were conducted in three urban centers in southern Ontario, Canada, in 2008-2009, after same-sex marriage was legally recognized in that province (in 2003). All of the participants had held their weddings within the six-year period prior to their interview.

Participants were recruited through public advertisements placed in local newspapers, as well as flyers distributed to local businesses, community centers, universities and LGBTQ organizations. Electronic announcements were sent out on various interest-based listservs. Flyers were handed out to participants in LGBTQ Pride events. Our sample includes twentyseven interviews of women married to men and nineteen interviews of women married to women. Only one woman per married couple was interviewed; none of the women in this study are married to each other. Only two of our twenty-seven participants in straight marriages $(7 \%)$ had been married previously. Five of our nineteen participants in same-sex marriages (26\%) had been married previously-all previous marriages in this group were to men. While these data collection efforts were part of a larger project that also included men and unmarried couples, for this study, we focus on married women's experiences with their own weddings to focus on a particular cultural practice that has been socially attached to brides and women's gender roles.

The women in our sample range in age from 23 to 55 . The sample is $82 \%$ white. This is similar to the racial demographics of Ontario, where the $200 \mathrm{I}$ census reports $19.1 \%$ of the province's population belong to the "visible minority," or non-white, category (Ontario Ministry 
of Finance 2003). Our sample also includes these self-reported racial and ethnic categories: three Asian and South Asian women, three Black women, two Latina women, and one participant of mixed race. Please see Table I for participant characteristics. All participants were assigned pseudonyms.

\section{Table I: Participant characteristics}

\begin{tabular}{|c|c|c|c|c|}
\hline & \multicolumn{2}{|c|}{ Straight marriage } & \multicolumn{2}{|c|}{ Same-sex marriage } \\
\hline & $n$ & $\%$ & $n$ & $\%$ \\
\hline Total participants & 27 & & 19 & \\
\hline Mean age & 34 & & 38 & \\
\hline - youngest & 24 & & 23 & \\
\hline - oldest & 51 & & 55 & \\
\hline \multicolumn{5}{|l|}{ Household income category* } \\
\hline - less than $\$ 60,000$ & 16 & $59 \%$ & 2 & $11 \%$ \\
\hline$-\$ 60,000$ or more & 10 & $37 \%$ & 17 & $89 \%$ \\
\hline \multicolumn{5}{|l|}{ Education } \\
\hline - Less than 4-year university & 6 & $22 \%$ & 3 & $16 \%$ \\
\hline - 4-year university degree or more & 21 & $78 \%$ & 16 & $84 \%$ \\
\hline \multicolumn{5}{|l|}{$\begin{array}{l}\text { Racial and ethnic category - self- } \\
\text { identified** }\end{array}$} \\
\hline - White & 20 & $74 \%$ & 17 & $89 \%$ \\
\hline - Black & 2 & $7 \%$ & 1 & $5 \%$ \\
\hline - Asian/South Asian & 3 & $11 \%$ & 0 & $0 \%$ \\
\hline - Hispanic or Latina & I & $4 \%$ & I & $5 \%$ \\
\hline - Mixed race or other & I & $4 \%$ & 0 & $0 \%$ \\
\hline Previously married*** & 2 & $7 \%$ & 5 & $26 \%$ \\
\hline
\end{tabular}

* Ontario median income in 2005 was $\$ 64,500$. One participant did not report income. ** Ontario "visible minority" population in 2001 was $19.1 \%$.

***All previous marriages were to men. 
Our semi-structured interviews were held in person either at a public location convenient to the participant or in the participant's home. Interviews were 1.5-2.5 hours in duration and used a standardized interview guide that asked a common set of questions to all participants, while allowing them to tell the stories of their experiences in their own words. While the interviews approached a broad range of topics related to their marriages and their relationship history, for this paper, we focus on their stories of their wedding ceremonies.

All interviews were audio-recorded and transcribed. These transcriptions were analyzed using Dedoose qualitative analysis software by the two authors and two research assistants. We used an iterative approach to coding that was partly directed and partly inductive (Creswell 20I3). First, the authors provided the research assistants with an initial directed coding framework derived from the research literature (Hseih and Shannon 2005). The research assistants each used this coding framework to code the transcripts, identifying sections of interview text that related to each theme, considering patterns of responses across individuals, and comparing the similarities across our two initial groups: straight marriages and same-sex marriages. The authors and research assistants met several times to discuss these themes, make additions and adjustments to the coding framework, and consider our preliminary findings. Each of us - research assistants and authors — completed several iterations of coding and analysis. We kept our key comparison in mind, analyzing straight-married women relative to the samesex married group, but we also approached the data inductively, allowing the words of our participants to direct our thinking. We wrote analytic memos and met to discuss our insights and develop our analysis. This approach pushed us to create the analytic categories that we present in this paper: non-reflexive adopters, acquiescent adopters, same-sex resisters, and frugal resisters. These analytic categories were inductively derived from the patterns of responses we saw in the data. Thus we incorporate both "prefigured" and "emergent" codes in 
analyzing these data (Crabtree and Miller 1992).

\section{FINDINGS}

We find a number of approaches to weddings that cluster into patterns of conformity and resistance to the traditional wedding ritual. Many of our participants in straight weddings conformed to the traditional wedding ritual, but a number of our straight participants resisted, as we discuss below. Our same-sex participants also split, but most of the women in our samesex marriage group resisted traditional wedding rituals. We detail the numbers of participants in each analytic group in Table 2.

\section{Table 2: Number of participants in each analytic category}

\begin{tabular}{lcc} 
Adopters & Straight marriage & Same-sex marriage \\
- non-reflexive & $\mathbf{1 7}$ & $\mathbf{4}$ \\
- acquiescent & 12 & 4 \\
& 5 & 0 \\
Resisters & 10 & $\mathbf{1 5 *}$ \\
- same-sex & - & 14 \\
- frugal & 8 & 7 \\
- other & 2 & 0 \\
\hline
\end{tabular}

*Six resisters are both same-sex and frugal.

\section{Consuming Modern White Weddings}

For a large number of our participants who are white, heterosexual, and/or middle class, participating in the modern white wedding constitutes a major life accomplishment and dream. Supporting Ingraham's critique of the wedding as a pathway to organizing life in connection to the institution of heterosexuality, many of our privileged participants embraced the traditional wedding without reflection or circumspection. For them, the white wedding was obvious and natural. We found that there were those who relished all aspects of the rituals of 
heterosexuality: the white wedding gown, an expensive ring, taking her husband's name, an extravagant cake, etc. Others, however, expressed some reticence about participating in aspects of the extremes of the consumerist and/or traditional ideal of the wedding industrial complex. For these women, pressure due to social or religious norms, or from their fiancé and/or family, trumped any true desire to resist the rituals embedded in the conventional white wedding. In the end, they all were led down a path that required an extravagant and formal event, often much more expensive and elaborate than anticipated.

Non-reflexive adopters.

Among our participants, heterosexual women were most likely to embrace the conventional wedding wholeheartedly. The non-reflexive adopters consciously embraced all the trappings and rituals of the traditional wedding. For example, Barbara's description of her wedding reveals that she did not feel critical of the traditional wedding, and so her wedding conformed to these expectations:

Traditional, simple, sweet. We did the traditional vows. I like the whole, just the whole ceremony was important. We didn't cut anything out; we didn't add anything in. It was just simple and sweet. It is just tradition is what I like. (Barbara, 38 , white, straight marriage)

Our participants also embraced wholeheartedly other aspects of traditional marriage rituals. Alice (40, white, straight marriage) expressed no qualms in taking her husband's name, for example: "It was important to him. He really wanted me to have his last name, and I really wanted to take it, so it wasn't a problem at all."

For many participants, the expectations of their wedding were institutionalized by the religious organizations that hosted the ceremonies, and the religious requirements were often quite explicit. Historically, Christian ideas defining marriage's purpose as procreation shaped 
marital traditions and continue to influence twenty-first century practices and views. Nancy, for example, emphasized the importance of religious tradition and having a full mass at her wedding:

We had a church wedding and then we had a reception after. It was long. Yeah, it was a full mass so it was about an hour. For me, it didn't seem long but for everyone else-like our guests - that was long. Yes, it was very traditional. (Nancy, 34, Asian, straight marriage)

Her church required participation in weekly services, and the bride and groom were allowed three choices of vows. She recounts: "This parish where we got married, you had to attend for a full year before they accepted you and, you know, said we can give you a date." In this case, getting married precipitated church attendance. Her experience underscores Ingraham's (2008) argument for the ways that religion has been key to producing a patriarchal social order and a gendered division of labor. Often, couples are required to participate in rituals that underscore patriarchal values.

Religion is important in determining norms and traditions. Other religions prevalent in North America may offer different traditions, but often these draw on dominant norms of traditional weddings. Dorothy belonged to a Mormon temple that had strict requirements for wedding rituals, clothing choices, and even which of her family members were allowed to participate. Even so her description elicits a traditional image of the modern wedding:

There's an alter that you kneel at. You're dressed in white, but you are wearing something very different on top of your white dress...there are no flowers. It's just a very beautiful room that you know was built that way. (Dorothy, 27, white, straight marriage)

Later, the couple held a separate ceremony to include a larger group of family and friends that conformed to dominant views of the conventional wedding. 
While religion still plays a role in determining tradition and guiding choices, several participants pointedly criticized the patriarchal traditions that attend some religious ceremonies. Yet, these non-reflexive adopters still opted for the conventional. Susan (26, mixed race, straight marriage) described how she and her fiancé modified the official vows:

It was really non-religious. [The] officiant gives you this ceremony, and [we] slashed through the vow kind of stuff, because making promises that are so strict and traditional-I'm not a very traditional person and [my husband] is a little more traditional than me-but at the same time, I don't think that I should vow to be a good housewife or whatever they put in those traditional type things.

Not too many heterosexual women these days vow to obey their husbands (which we assume is what Susan meant by vowing to be a good housewife). When pressed, Susan told us that their vows were based on the official ones that included few of their own ideas. Her description of the wedding followed convention; she explained that the "ceremony was kind of traditional.... I wore an off-white dress made out of lace and he wore his traditional tux."

Expectations of the ideal, heteronormative wedding conform to middle-class patterns of consumption (Ingraham 2008). The responses of our heterosexual participants displayed the ease with which they embraced all the accouterments of the modern wedding. Jennifer (33, white, straight marriage) summed up the taken-for-granted nature of the conventional white wedding directly when she considers why she had a bachelorette party and her fiancé had a bachelor party before the wedding: "Yep, I never really thought about it; you kind of do it because it is suppose to be done."

For Susan (quoted above), it was a dream come true: "I love the idea of marriage. A lot of girls really dream of having that ceremony, and I'm one of those people. I wanted the white 
dress and all that." For Elizabeth, her wedding had "all the essential components" of the conventional wedding:

And traditionally I wanted bridesmaids walking ahead of me.... I wanted a matron of honor and a best man to you know write in the register. I wanted you know the big hoopy gown... A photographer, the whole nine yards. (Elizabeth, 37, white, straight marriage)

Elizabeth's words offer strong support for the power of the heterosexual imaginary that makes all of the trappings of the conventional wedding seem obvious, part of every girl's dream. The ease with which our participants embraced this ideal was accompanied by evidence of more favorable attitudes toward spending a lot of money, throwing a large party, and consumerism in general among our straight participants. In particular, we find a greater comfort with the idea of having a big, expensive event among several (but not all) in the straight group. For example, several of our participants described how much they spent on their lavish wedding cakes. Elizabeth reminisced:

So I spent a fortune on my wedding cake, and I wouldn't exchange it for the world. I even had a groom's cake: 7 different types of chocolate in the groom's cake, and I had a great 3 tiered wedding cake, and I had 2 doves at the top instead of the official bride and groom kind of thing. (Elizabeth, 37, white, straight marriage)

Similarly, Linda also spent a lot of money on her wedding cake but wondered after if she should have:

It was a beautiful huge cake, like a 3 tier cake. [We got] this figurine thing to put on the top and it was beautiful but it was also expensive, it was like $\$ 150.00$ or something ridiculous like that. (Linda, 33, Asian, straight marriage)

Betty shared with us her story of hosting several get-togethers around the wedding:

We had an engagement party about six months after we got engaged. We had two bridal showers... and my husband had a stag. I think we had a dinner the night before as well and an event for people from out of town... [and a reception after the wedding]. 
Yes, because that's sort of what everyone else does. And also, your guests come from far away and you want to give them a party. And you also don't want to look cheap! (Betty, 3l, white, straight marriage)

Her words reveal the social pressures she felt to conform to this consumerist model of wedding planning, providing insight about the consequences of failing to throw all of these parties: "looking cheap" to her family and friends. Her wedding spending established her reputation as a person with "class" and generosity; she was able to communicate her middleclass status through these celebrations.

Acquiescent adopters.

While many of our straight participants wholeheartedly embraced the conventional and/or consumerist model of weddings, some desired ceremonies that were a little less extravagant and ostentatious than the ideal and its traditional requirements. While our acquiescent adopters imagined weddings that were non-traditional, in the end they often still seemed to conform to the standard white wedding. Helen (33, white, straight marriage), for example, at first opted for the more progressive wedding ritual at her Greek Orthodox church, which gave her the choice of walking down the aisle with both her mother and father, or just her father. However, she chose the traditional path: "I had the choice of just my dad or my mom and my dad, but my mom didn't want to. She was just a little embarrassed. And it's also a little tight, [the aisle], it's narrow, so here I had this dress, and it was just my dad and I." Ultimately, her mother's embrace of tradition and Helen's consumption patterns decided her path to taking the more conventional option.

Some heterosexual participants explicitly expressed difficulty in deciding aspects of the wedding ceremony due to reservations about tradition. Shirley (27, white, straight marriage) described how chance ultimately provided them a way to buck tradition a bit: 
Picking out who [to officiate] the ceremony was the most challenging part for me. I only knew [one minister] from when my grandmother passed away and he did the funeral. He's a nice guy but I didn't really have a relationship with him. My husband is not religious at all, and I don't think he would have been opposed, but there didn't seem to be a real logical choice for us. So that's why we ended up looking on the Internet. It's interesting because [the person we chose] was a minister but I think he was gay, which appealed to us-particularly to my husband. I'm not sure why, just because there are no rules imposed on it.

Shirley's response to tradition is reminiscent of Susan's, the non-reflexive adopter above, who described herself as non-traditional but wasn't able to articulate anything more than cutting out the vows relating to obedience. Shirley is a bit more reflexive concerning the reasons why it pleased the couple to have a gay minister-to resist the rules-but it was left up to chance to find an officiant who was not conventional.

Our participants also succumbed to outside pressures and expectations of what it means to get married. In the following two cases, this meant buying a more extravagant wedding gown than expected. Patricia thought of herself as non-traditional at the beginning of the wedding planning process, but found herself moving to a traditional white wedding as the date got closer:

I wanted a really simple dress, but I thought white would be good... And the plain dresses I tried on I was like, I just look like I'm wearing a white dress, I don't look like it's my wedding, so I ended up getting a dress that was way fancier, way bigger, way more expensive than I EVER planned... So we ended up doing a pretty....in that sense, pretty traditional wedding. (Patricia, 27, white, straight marriage)

Often, women yielded to the desires of their future husbands. Alice already had a white wedding for her first marriage, and she told us that she did not need such an elaborate affair for her second wedding. However, her fiancé felt differently:

So, I said to Jim on the second wedding "how would you, what kind of dress do you, do you think? The big fancy dress? Just the plain white dress for me, just, 
what do you think?', he said 'no, I would love it if you would like to wear a really

fancy wedding dress', so that's what I got... (Alice, 40, white, straight marriage)

Similarly, pressures from their husbands decided other important traditions for our participants, like whether to take their husband's name. Carol (26, white, straight marriage) described her decision as something unimportant to her but important to her husband: "For him it was really important that I took on his name. That wasn't as important to me, but it was important to him." Thus, something as significant as changing one's name is done based on the husband's desire.

Responses that highlight the ways that women surrender to the desires of their husbands or families reveal some of the social forces captured by the symbolism of the conventional white wedding. They suggest that it is not simply the product of individual brides' preferences; rather, this is a larger cultural phenomenon, a set of social norms that is enforced through negotiations with partners, parents, family and friends who share a singular vision of what a wedding should look like. There is a stickiness about the white wedding that draws many, but not all, of our straight-marriage participants to these rituals. In contrast, very few of our same-sex marriage participants readily consumed the conventional wedding. In the next section we outline the ways that some of our straight-marriage and most of our same-sex marriage participants resisted the trappings of the traditional wedding.

\section{Resisting Modern White Weddings}

While our more privileged participants tended to either embrace or passively submit to the trappings of the conventional wedding, other participants expressed their outsider status to the heteronormative, class-privileged, and consumption-based norms inherent in the ritual of traditional weddings. Women who participated in same-sex weddings were much more likely to 
consciously resist and/or offer criticisms of ritualized elements of the white wedding. Likewise, some of our participants leveled critiques at the lavish excesses of the ideal wedding, embracing a more subdued ceremony in line with their own sensibilities of thrift or simplicity.

Same-sex resisters.

Not all of our same-sex marriage participants were critical of traditional weddings. A small number of this group embraced the symbolism of the white wedding with enthusiasm. Frances and her partner created a ceremony in which both brides wore white wedding gowns, and that followed a fairly standard white wedding template:

We had a piper, and she had special music, and we had singers, fairly conventional. Flowers, vows, which we made, the church also, you know, guides you along, but we said our own vows at one point, and we exchanged rings. (Frances 47, white, same-sex marriage)

One of our participants made the case that having a traditional, white wedding ceremony as a same-sex couple was a radical act of resistance. Echoing the findings of Hull (2006), whose respondents viewed same-sex commitment ceremonies as a radical act of protest, Judith, an immigrant from Trinidad, thought of her traditional white wedding as a statement of defiance against heteronormativity:

I saw it as very radical. Like here I am, who would have thought my life would end up l'm living in this country where [she] and I could get married... People would talk about "Oh, you're joining the conventional" and we're just copying them, but I was like "This is the most radical thing that can happen," and what marriage was as an institution and for a woman to become married, for a woman to marry another woman was the most radical thing. (Judith, 35, Black, same-sex marriage)

For many of our same-sex marriage participants, however, the white wedding was a ritual that they grappled with critically. Most acknowledged criticisms of heteronormative marriage in general and traditional weddings in particular, and many of them sought to create 
wedding ceremonies that were at a distance from these social expectations. These same-sex resisters actively engaged with feminist and queer criticisms of marriage as they decided whether to get married and as they planned their weddings. For example, in the opening quote of this paper, Catherine (4I, white, same-sex marriage) tells us that she would be challenged by her queer friends about "taking on a heterosexual form for the relationship." Similarly, Carolyn thoughtfully considered a feminist critique of marriage before taking the plunge:

There seemed to be a feminist sort of feeling that if you get married you're buying into something that's been used by patriarchy for generations...that this is an institution created to keep your women down a little bit. But I think that it's kinda, that might have been how it was established initially, but that it's not really like that anymore. It's evolved. (Carolyn, 37, white, same-sex marriage)

Many in our same-sex marriage group shared similar considerations of criticisms of marriage, even as they decided to get married. These concerns were also reflected in their engagement with the cultural norms regarding conventional weddings as well.

Unlike our acquiescent adopter group, these same-sex resisters were able to successfully resist the social norms pulling them toward a traditional ceremony. They accomplished this in large measure by holding their weddings outside of religious institutions and by limiting the role of their extended families in the wedding planning process. For example, when Evelyn talked about her wedding, she addressed the role of family and religion in upholding heteronormative wedding rituals:

We decided to have the City Hall ceremony to take care of that aspect of the notion of marriage ... And then the next day, when we realized that we didn't now need to fit any forms or have a minister present, that we could do whatever we wanted, it really freed up what we did in our ceremony. (Evelyn, 3I, white, same-sex marriage)

Evelyn's ceremony, then, was a very woman-centered ritual that drew on pagan, Wiccan traditions: 
We decided to have the four ages of women represented, so there was the girl, the maiden, the mother and the crone... What we did was we had these four women or girls marry us, instead of a minister. (Evelyn, 3I, white, same-sex marriage)

Holding a wedding in a non-traditional location created opportunities to create ceremonies that were distinct from traditional weddings. For example, Carolyn had her wedding in a local pub:

We got married in a bar...by [a] friend from university who is a minister in a church... We got rid of the parents holding candles parts... we got rid of the family stuff, we got rid of the Jesus stuff... we had cupcakes. But not a specific wedding cake, no. (Carolyn, 37, white, same-sex marriage)

Distance from families of origin and extended kin also reduced the social pressures on those participants who had criticisms of the traditional wedding ceremony. Many who held same-sex weddings told us stories of rejection by parents, uncles, grandparents, and so on. Often, they had painful memories of relatives who declined to attend their wedding ceremonies. As difficult as these broken ties were for our participants, it became clear that those who had more distance from their kin had more autonomy in determining the content and style of their wedding ceremony. For example, Diane's family did not attend her ceremony:

So that was the only family that came, because I didn't want to invite, even though everyone knew in my family, also extended aunts, uncles and so forth, we only like, just because I think we were so outside of the framework and of expectations that it was actually easier to just really do what we felt for, and it just felt right to only have our very close friends at the ceremony. (Diane, 3I, white, same-sex marriage)

Diane was able to plan her own wedding outside the script of the white wedding, because she felt "outside the framework" of heteronormative tradition, and because her family did not participate in the planning. 
A few same-sex marriage participants would have preferred to have a formula to follow, but their critical reflection on the symbolism of the white wedding would not allow them to do that. For example, Rose said:

I mean in a way it is kind of cool because, because we are free, some degree we have the freedom to invent our own traditions right, but then it is also kind of a burden because it's not ready set unless you want to do it kind of the same religious standard wedding, which we didn't want. (Rose, 43, white, same-sex marriage)

This actively critical approach to weddings extended into other aspects of heteronormativity, such as changing one's surname. Unlike our straight-marriage participants, very few of our same-sex marriage participants changed their surnames when they were married. Those who did change their names had much more elaborate explanations for doing so, once again indicating that they thought deeply about the same issues that our middle-class, heterosexual group took for granted. For example, Nicole changed her name because she worried that her family may be considered illegitimate by authorities. She thought that a common name for all family members would help:

And to change my name, and if anything happens to me, my children that everything's okay for [my wife]. I don't have to worry about my ex [gaining custody of the children]. (Nicole, 39, white, same-sex marriage)

Overall, our same-sex resisters were aware of the heterosexual imaginary, but they were critical of it, choosing not to participate. Unlike our heterosexual respondents, who were more likely to uncritically participate in the "superbride" culture, even when they considered themselves to be resistant to tradition, our same-sex resisters were successful in their attempts to hold a ceremony that was outside of these traditions. For same-sex couples, engagement with the heterosexual imaginary was deliberate and self-conscious. Those few who chose a traditional wedding saw themselves as resisting heteronormativity, as did the majority who 
created non-traditional ceremonies. Their success in resisting was aided by a distance from families of origin and by limiting the role of religious institutions.

Frugal resisters.

Participants in our same-sex marriage group were not the only group to criticize traditional wedding ceremonies and the excessive consumption they require. Our interviews also revealed what we interpret as a critique of traditional wedding ceremonies that values thrift and prudence-a working-class criticism of the extravagant, traditional wedding. This critique is distinct from the elaborate engagement with heteronormativity that was common among our same-sex marriage participants. Instead, this criticism was a simple, direct dismissal of traditional weddings as costly and wasteful. This thrift-based critique was made by both straight and same-sex participants who criticized the consumerist aspects of the traditional wedding more than the heteronormative.

Participants in our frugal resisters category held small ceremonies in chapels, at City Hall, or in non-traditional locations. They eschewed the practice of having multiple parties, dinners and rehearsals, while retaining what was meaningful for them about their wedding ceremony. For example, Karen had a simple ceremony with twenty-five guests:

The ceremony itself, it was, it was [held in] an old house that they've converted into a hotel... It was very no-nonsense. And I guess... we're kind of no-nonsense people, so it was nothing over the top. (Karen, 35, white, straight marriage)

In several cases, the practices that the frugal resisters substituted for the expensive purchases were also expressions of family and community support for the couple. In lieu of an expensive catered dinner for guests, homemade food was prepared by family and friends. Rather than paying hundreds of dollars for a bakery-made wedding cake, simple cakes were 
baked and decorated at home. Guest lists were smaller, limited to close family and friends. For example, Lisa had a small ceremony at City Hall, followed by a barbecue at a girlfriend's home:

It wasn't that kind of wedding... It was a dress, straight white dress, but I had no veil, no gloves, no nothing... We had lunch, we made our own food, we had prepped all that food beforehand, and then a bunch of our friends brought like sandwiches and chips, you know a bunch of friends brought booze and everything... it was like super casual, it was like barbeque. (Lisa, 38, Black, straight marriage)

Similarly, Donna's family pitched in with their talents for her small, cost-conscious wedding:

It was very small, there were twenty-two people including us. My cousin, who's a musician, did the music. Her sister, who's a chef, did the cake, and my brother, ... he did the car. (Donna, 5I, white, straight marriage)

The frugal resisters group offered sharp, brief criticisms of traditional weddings that suggested they were completely out of sync with their self-concept. Deborah (35, Latina, straight marriage), who had a ceremony in her parents' back yard and baked a simple two-layer cake, said "No, no no.... we just thought it was dumb." Sharon (34, white, straight marriage), when asked about traditional weddings, said simply, "I think they're a waste of money." Nicole (39, white, same-sex marriage), said, "My sisters got married and the big fancy do, and I just thought it was a big waste of money." These sharp, simple criticisms reveal that our frugal resisters group did not feel pushed into spending more than they wanted to by friends or family. Like our same-sex resisters, this group tended to hold their weddings outside of religious institutions.

Jean, a participant who falls into both our same-sex resister and frugal resister categories, had a more extensive critique of the consumerist aspects of traditional weddings: 
I think that sometimes they are a little over the top. Like to me, I think, we had something great that was focused on what was important. The big thing, wanting to show off, like, look what I can afford and how much are you going to give me... did you give us as much as we spent on your dinner, traditional wedding, I think makes me feel nauseous. (Jean, 44, white, same-sex marriage)

Jean argued that the consumerism of traditional wedding is at odds with her vision of a meaningful connection between herself and her partner, shared with close family and friends. She saw a frugal wedding ceremony as a purer expression of her values.

Carolyn also criticized traditional wedding practices, especially the expectation of wedding and shower gifts:

[My partner] felt that the whole thing, the shower was just a money grab, and all about getting the wife some toasters, that kind of thing... On our invitations we asked people to give donations to Project Read, so that was on the invitation instead of gifts for the wedding, and we just told everybody "no shower." (Carolyn, 37 , white, same-sex marriage)

To Carolyn, the traditional practice of expecting guests to provide gifts at a wedding is selfish and greedy. It is inconsistent with her values. She felt free to create a wedding that was a closer match to what she and her partner felt was important and meaningful. The importance of bringing two families together was echoed by Kimberly, who also had a frugal wedding:

The actual wedding was very small, it was just immediate family and friends only, and it was at City Hall... No stag, no stagette, but we did have family get together, and that was about it. Just a little informal dinner... It was important for me to do that, because then it's the family and friends getting together and sitting down and talking and speaking and interacting with one another on both sides.... We honeymooned in town (laughing)... Just the weekend. Kimberly (47, black, straight marriage)

Some of our frugal resisters were not critical of traditional weddings. These participants enjoy big weddings, and even imagined one for themselves. However, they simply decided that 
their spending priorities lay elsewhere. For example, Alicia is a Mexican-American who immigrated from the United States to Canada with her partner, whose student visa from Mexico was about to expire. As she could not sponsor the immigration of her same-sex partner to the United States, the couple moved to Canada to start a life together and get married. They both wanted a large, traditional Mexican wedding, but they decided they couldn't afford it, opting instead for a small ceremony at City Hall:

With all my family...eight siblings, plus the spouses, plus I have fifteen nephews and nieces and their girlfriends and her family in Mexico. We just sat down one day and started like writing out like people-and we lived in a one-bedroom [apartment at the time]...it just got too complicated...so yeah it was a little disappointing, but on the grand scheme of things I think it worked out better. We saved a lot of money, and now we have a condo...so, yeah we are happy the way it turned out. Alicia (40, Latina, same-sex marriage)

Our frugal resisters may see the traditional wedding ceremony as negative, positive, or something in between, but one thing they have in common is that they understand it to be optional. They feel comfortable that they can choose to spend money on a wedding or opt for a different route, without suffering too many social consequences for their choices. They were able to think critically about traditional weddings, and unlike our acquiescent adopters, these brides successfully crafted wedding ceremonies that fit their identities, values, and budgets.

\section{DISCUSSION}

All four of our analytic categories—non-reflexive adopters, acquiescent adopters, same-sex resisters, and frugal resisters-engage with the heterosexual imaginary described by Ingraham (2008), whether to adopt or resist this formulation of traditional weddings. We have created these categories inductively based on our analysis of our participants' own words about what their wedding ritual means to them. These categories suggest an alignment with social forces 
such as sexual identity, class, and race. Our interview data, however, do not allow us to make causal claims about how class and sexuality affect wedding choices. For example, we do not make the claim that all working-class brides act one way and middle-class brides another. Instead, we offer an analytic framework grounded in the lived experiences of our research participants, leaving it to future research to test the merit of these categories on a larger, more diverse population of brides.

This research confirms the power and the limits of the lavish white wedding to perpetuate heteronormative understandings of modern coupledom and the importance of religion and consumerism in this process. Our participants — whether planning a straight or same-sex wedding - had to deal with the conventional wedding as a cultural ideal that shaped their choices. All viewed heterosexual marriage as a point of reference, either as the unquestioned standard that supports tradition or as a structure that must be negotiated and/or resisted when planning the big day. Currie (1993) and Ingraham (2008) argue that contemporary North American norms of conventional weddings reproduce and enforce a set of hegemonic understandings of not only weddings themselves, but also of a particular configuration of a patriarchal nuclear family. The cultural trope of the traditional wedding, they argue, reinforces a hierarchy of family forms which privileges and naturalizes male-dominated marriages and traditional gender roles. Our findings support this perspective, showing that many of our participants preferred and took for granted these hegemonic understandings of the family. While enduring, internally gender-stratified marriages are on the decline, the "meaning constitutive tradition" of romantic love has become enmeshed with standards of consumption and religious rituals to fortify the importance of the lavish, fairytale wedding in perpetuating the heterosexual imaginary (Gross 2005:288; Ingraham 2008; Otnes and Pleck 2003). 
Our findings contribute to the critical study of heterosexuality by calling attention to the importance of comparative research that illuminates different strategies used to adopt or resist the heteronormative and consumerist structures of wedding planning. We uncover important differences in the ways that individuals go about deciding their weddings based on social context. For many of our privileged women who planned a straight ceremony, the specifics of the conventional wedding were incorporated without reflection. Some relished their role as "superbride" who spent lavishly to make their special day memorable (Boden 2003). Even those who sought some distance from the iron cage of tradition incorporated aspects of the conventional white wedding into their ceremonies without much concern. This latter group was acquiescent in adopting traditions due to pressures from family or from their future husbands. They consented to wearing extravagant, white wedding gowns with all the frills when a husband or family member expressed this preference, and they changed their names when asked by their husband to do so. These testimonies confirm research that identifies the power of the conventional wedding and its rituals-religious and non-to perpetuate traditional gender roles and reproduce unequal marital relations (Baker and Elizabeth 2013; Humble et al. 2008).

While our participants all engaged the cultural ideal of the lavish conventional wedding, whether to embrace or reject it, there were substantial differences for those planning sex-same ceremonies. For these individuals, the conventional wedding tended to be much more fraught. A few fell solidly in the homonormative camp, embracing wholeheartedly the lavish wedding cake, the white dress or dresses, and numerous parties, etc. Yet, even those who adopted the traditions of the conventional wedding tended to see this embrace as a "radical" move, a form of activism to participate in an institution from which same-sex couples were once excluded (Hull 2006; Taylor et al. 2009). In contrast, the majority of our participants were critical of the 
conventional wedding and incorporated ceremonies and practices that honored their status as outsiders to the heterosexual imaginary. They negotiated what felt right for them in connection to their families, who varied in their supportiveness of the big event, and their friends, who some felt to be more important witnesses to the event than family members.

Our findings corroborate the importance of studying same-sex marriage as a lived institution that individuals must negotiate in complex ways (Baker and Elizabeth 2012; Green 2010; Humble 2013; Macintosh et al. 2010; Shipman and Smart 2007; Smart 2008). Specifically, criticisms of same-sex marriage leveled by social conservatives and critical feminist/queer theorists - albeit from profoundly different political positions - tend to simplify the terms of the same-sex marriage debate in ways that fail to capture the thoughtful processes undertaken by same-sex couples who marry. Our findings show that women planning a same-sex wedding were acutely aware of the possibility that their ceremony might emulate heterosexual practices. Similar to the couples that Smart (2008) interviewed, our respondents recounted a decisionmaking process that included compromises between competing principles and desires. To this order, our participants resisted the enticement of the heterosexual imaginary by holding their weddings in non-traditional settings and by including "families of choice" in the planning process rather than just relying on biological ties (Weston I991).

Adam Isaiah Green (20I0) argues that same-sex couples who choose to marry do so on their own terms, adopting a range of nontraditional practices that ultimately destabilize the institution of marriage. Our findings support Green's perspective, demonstrating a range of creative, unique wedding rituals that do not follow the traditional norms. These findings highlight the ways that same-sex couples may ultimately transform the ritual aspects of weddings more than themselves being transformed by this heteronormative institution. 
Perhaps more surprising than the resistance strategies of women planning a same-sex wedding were those of women planning a straight ceremony. Current scholarship on weddings did not anticipate the finding that class orientation, and perhaps race (see below), would mitigate the consumerism of the lavish wedding for straight women. Many of our respondents reported a desire for thrift and prudence in planning their big day, offering a working-class critique of the overindulgence of traditional weddings. Their reflections did not engage critiques of heteronormativity; rather, these women offered an analysis of the overpriced and indulgent qualities of lavish weddings. Blakely's (2008) study of wedding planners uncovered how privileged career women turned to this profession to farm out their wedding planning as a way to "have it all." Their class privilege meant that they could outsource the gendered division of labor to others, and thus partially escape some of the burdens of orchestrating a lavish wedding.

The frugal resisters in our study did not have the material resources to outsource their wedding work, nor would it seem that most would have done so if they had the means. Unlike the adopters who either offered no critique of the wedding culture or who readily acquiesced to others, our resisters presented thoughtful reflections about why they chose economical ceremonies over lavish ones. They critiqued rituals like wedding showers as representing a “money grab," and preferred small intimate, non-religious ceremonies with close family and friends. All of our Black and Latina participants fell into these resister categories. However, while our sample reflects the overall racial diversity of Ontario, our predominantly white sample allows us only to speculate that race might make a difference in the kinds of critiques women level against participating in the lavish wedding culture. Future research should consider the ways that race matters in the wedding planning process.

Our frugal resisters are not the low-income heterosexual women that Edin and Kefalas (2005) studied, who expressed a desire to marry but were currently cohabiting until they could 
save enough money for a "real wedding." In contrast, many of our resisters, likely more classprivileged and more educated than the women in Edin and Kefalas's study, offered critiques of what is meant by a "real wedding." They may not have had the means to finance a lavish wedding, but this did not stop them from planning a ceremony that felt "right" for them. There is also evidence that individuals who remarry may approach their weddings in different ways, both in terms of gender construction and in terms of consumerism (Humble 2009). Only two of our participants in straight marriages had been married previously, and both of these women chose traditional ceremonies. Of our participants in same-sex marriages, all of whom had been previously married to men, three chose frugal ceremonies. Thus, we cannot adequately assess possible differences. Future research should study the wedding planning among individuals who were previously married.

\section{CONCLUSION}

Same-sex marriage is a recent phenomenon in Canada, and as time passes, more normalization of same-sex weddings is likely to occur. It will be important to conduct further research into how women planning same-sex weddings engage the heterosexual imaginary to uncover possible evolution in attitudes. We predict that the historical legacy of being a sexual outsider will continue to influence women's perspectives on same-sex weddings. We limited our research to the comparative experiences of women who planned their same-sex or straight weddings. Future research should also examine the comparative experiences of men in wedding planning. Some men—though a minority of them—do participate in the planning of straight weddings (Humble et al. 2008). There is also a growing consumer market for wedding planning targeting women and men entering into same-sex marriages, including advice books for planning 
the perfect same-sex ceremony. Green (2010) found significant differences in the ways that men and women view marriage, monogamy, and commitment in their same-sex marriages. Future research should assess potential differences between men and women in planning a same-sex wedding.

In conclusion, the cultural hegemony of the traditional wedding marginalizes women who are outsiders due to their sexual orientation and/or do not have the means to pull off the extravagant event that is so intertwined with the heterosexual imaginary. Overall, women planning a same-sex wedding expressed awareness of their outsider status, even as same-sex marriage in Ontario has been legal since 2003. In contrast, our frugal resisters did not necessarily view themselves as outsiders but offered sharp critiques of consumer culture that helps to perpetuate the dominant ideal of conventional weddings. Our comparison of women planning same-sex and straight weddings provides valuable insight into the complexities of negotiating heteronormative structures and the circumscribed agency that many of these women employ to escape the demands of the fairytale. 


\section{REFERENCES}

Baker, Maureen, and Vivienne Elizabeth. 2012. “Negotiating 'Marriage': Comparing Same-Sex and Different-Sex Cohabiting Couples.” New Zealand Sociology 27(2): 10-28.

Baker, Maureen, and Vivienne Elizabeth. 2013. “'Did You Just Ask Me to Marry You?': The Gendered Nature of Heterosexual Relationship Progressions.” Women's Studies Journal $27(2): 32-43$.

Bernstein, Mary, and Verta Taylor. 2013. "Marital Discord: Understanding the Contested Place of Marriage in the Lesbian and Gay Movement." Introduction, The Marrying Kind? Debating Same-Sex Marriage within the Lesbian and Gay Movement, edited by Mary Bernstein and Verta Taylor. Minneapolis, MN: U of Minnesota Press.

Blakely, Kristin. 2008. "Busy Brides and the Business of Family Life: The Wedding-Planning Industry and the Commodity Frontier.” Journal of Family Issues 29(5):639-662.

Boden, Sharon. 2003. Consumerism, Romance, and the Wedding Experience. New York: Palgrave Macmillan.

Crabtree, Benjamin F., and William L. Miller, eds. 1992. Doing Qualitative Research. Newbury Park, CA: Sage Publications.

Creswell, John W. 2013. Qualitative Inquiry and Research Design: Choosing among Five Approaches. 3rd ed. Los Angeles, CA: SAGE Publications.

Currie, Dawn H. 1993. “'Here Comes the Bride’: The Making of a 'Modern Traditional' Wedding in Western Culture.” Journal of Comparative Family Studies 24(3):403-422.

Duggan, Lisa. 2003. The Twilight of Equality?: Neoliberalism, Cultural Politics, and the Attack on Democracy. Boston: Beacon Press.

Edin, Kathryn, and Maria Kefalas. 2005. Promises I Can Keep: Why Poor Women Put Motherhood Before Marriage. Berkeley: University of California Press. 
Eskridge, William N. Jr. 1996. The Case for Same-Sex Marriage: From Sexual Liberty to Civilized Commitment. New York: Free Press.

Green, Adam Isaiah. 2013. "Debating Same-Sex Marriage: Lesbian and Gay Spouses Speak to the Literature." Chapter II in The Marrying Kind? Debating Same-Sex Marriage within the Lesbian and Gay Movement, edited by Mary Bernstein and Verta Taylor. Minneapolis, MN: University of Minnesota Press.

Green, Adam Isaiah. 2010. “Queer Unions: Same-Sex Spouses Marrying Tradition and Innovation." Canadian Journal of Sociology 35:399-436.

Gross, Neil. 2005. “The Detraditionalization of Intimacy Reconsidered." Sociological Theory 23(3):286-3II.

Heath, Melanie. 2009. "State of Our Unions: Marriage Promotion and the Contested Power of Heterosexuality." Gender \& Society 23(I):27-48.

Hsieh, Hsiu-Fang, and Sarah E. Shannon. 2005. “Three Approaches to Qualitative Content Analysis." Qualitative Health Research 15(9):1277-88.

Hull, Kathleen E. 2006. Same-Sex Marriage: The Cultural Politics of Love and Law. Cambridge, UK: Cambridge University Press.

Humble, Áine M. “The Second Time 'Round: Gender Construction in Remarried Couples' Wedding Planning." Journal of Divorce and Remarriage 50(4):260-28I.

Humble, Áine M. 2013. "Moving from Ambivalence to Certainty: Older Same-Sex Couples Marry in Canada." Canadian Journal on Aging / La Revue canadienne du vieillissement 32(2): $13|-| 44$.

Humble, Áine M., Anisa M. Zvonkovic, and Alexis J. Walker. 2008. “'The Royal We': Gender Ideology, Display, and Assessment in Wedding Work." Journal of Family Issues 29(I): 3-25. 
Ingraham, Chrys. 2008. White Weddings: Romancing Heterosexuality in Popular Culture. New York: Routledge.

Jowett, Adam, and Elizabeth Peel. 2010. "'Seismic Cultural Change?': British Media Representations of Same-Sex 'Marriage..' Women's Studies International Forum 33:206-214. Kandaswamy, Priya. 2008. "State Austerity and the Racial Politics of Same-Sex Marriage in the US." Sexualities 11:706-25.

Kimport, Katrina. 2013. Queering Marriage: Challenging Family Formation in the United States. New Brunswick, NJ: Rutgers University Press.

Kimport, Katrina. 2012. "Remaking the White Wedding? Same-Sex Wedding Photographs' Challenge to Symbolic Heteronormativity." Gender \& Society 26(6):874-99.

Kitzinger, Celia, and Sue Wilkinson. 2004. "The Re-Branding of Marriage: Why We Got Married Instead of Registering a Civil Partnership." Feminism \& Psychology 14:127-50.

Lewin, Ellen. 1998. Recognizing Ourselves: Ceremonies of Lesbian and Gay Commitment. New York: Columbia University Press.

Macintosh, Heather, Elke D. Reissing, and Heather Andruff. 2010. "Same-Sex Marriage in Canada: The Impact of Legal Marriage on the First Cohort of Gay and Lesbian Canadians to Wed." Canadian Journal Of Human Sexuality 19 (3):79-90.

Ontario Ministry of Finance. 2003. Census 200 I Highlights: Factsheet 6: Visible Minorities and Ethnicity in Ontario. Ontario. Retrieved April 16, 2015 (http://www.fin.gov.on.ca/en/economy/demographics/census/).

Otnes, Cele C., and Elizabeth H. Pleck. 2003. Cinderella Dreams: The Allure of the Lavish Wedding. Berkeley: University of California Press. 
Rolfe, Ailson, and Elizabeth Peel. 20I I. “'It's a Double-Edged Thing': The Paradox of Civil Partnership and Why Some Couples are Choosing Not to Have One." Feminism \& Psychology 2I(3):317-335.

Roseneil, Sasha. 2002. “The Heterosexual/Homosexual Binary: Past, Present and Future.” Pp. 27-43 in Handbook of Lesbian and Gay Studies, edited by Diane Richardson and Steven Seidman. London: Sage Publications Ltd.

Rubin, Gayle. 1984. “Thinking Sex: Notes for a Radical Theory of the Politics of Sexuality.” Pp. 267-319 in Pleasure and Danger: Exploring Female Sexuality, edited by Carole S. Vance. London: Routledge \& Kegan Paul.

Schecter, Ellen, Allison J. Tracy, Konjit V. Page, and Gloria Luong. 2008. "Shall We Marry? Legal Marriage as a Commitment Event in Same-Sex Relationships." Journal of Homosexuality 54(4):40I-422.

Shipman, Beccy, and Carol Smart. 2007. '“It's Made a Huge Difference': Recognition, Rights and the Personal Significance of Civil Partnerships.” Sociological Research Online I2 (I). Available at http://www.socresonline.org.uk//2/l/shipman.html.

Shulman, Julie L., Gabrielle Gotta, and Robert-Jay Green. 20I2. “Will Marriage Matter? Effects of Marriage Anticipated by Same-Sex Couples." Journal of Family Issues 33(2):I58-|8|.

Smart, Carol. 2008. '“Can I Be Bridesmaid?' Combining the Personal and Political in Same-Sex Weddings." Sexualities II (6): 76I-776.

Stoddard, Thomas B. 1992. "Why Gay People Should Seek the Right to Marry." Pp. 13-27 in Lesbian and Gay Marriage: Private Ceremonies, Public Commitments, edited by Suzanne Sherman. Philadelphia, PA: Temple University Press. 
Taylor, Verta, Katrina Kimport, Nella Van Dyke, and Ellen Ann Andersen. 2009. "Culture and Mobilization: Tactical Repertoires, Same-Sex Weddings, and the Impact on Gay Activism.” American Sociological Review 74:865-90.

Tombaugh, Alissa. 2009. "Pretty Dresses and Privilege: Gender and Heteronormativity in Weddings." Sociological Insight I:I06-123.

Valverde, Mariana. 2006. "A New Entity in the History of Sexuality: The Respectable Same-Sex Couple." Feminist Studies 32:155-62.

Weston, Kath. 199I. Families We Choose: Lesbians, Gays, Kinship. New York: Columbia University Press.

Wolfson, Evan. 2004. Why Marriage Matters: America, Equality, and Gay People’s Right to Marry. New York: Simon \& Schuster. 


\section{Appendix A: Participant details}

\begin{tabular}{|c|c|c|c|c|c|c|}
\hline Pseudonym & $\begin{array}{c}\text { Marriage } \\
\text { type }\end{array}$ & Age & $\begin{array}{l}\text { Participant's } \\
\text { race/ethnicity }\end{array}$ & $\begin{array}{c}\text { Spouse's } \\
\text { race/ethnicity }\end{array}$ & Analytic Group & $\begin{array}{l}\text { Previous } \\
\text { marriage? }\end{array}$ \\
\hline Linda & Straight & 33 & Asian & White & Non-reflexive adopter & no \\
\hline Barbara & Straight & 38 & White & White & Non-reflexive adopter & no \\
\hline Jennifer & Straight & 33 & White & White & Non-reflexive adopter & no \\
\hline Susan & Straight & 26 & Mixed race & Asian & Non-reflexive adopter & no \\
\hline Dorothy & Straight & 27 & White & White & Non-reflexive adopter & no \\
\hline Nancy & Straight & 34 & South Asian & South Asian & Non-reflexive adopter & no \\
\hline Betty & Straight & 31 & White & White & Non-reflexive adopter & no \\
\hline Jessica & Straight & 31 & White & White & Non-reflexive adopter & no \\
\hline Michelle & Straight & 44 & South Asian & South Asian & Non-reflexive adopter & yes \\
\hline Laura & Straight & 29 & White & Asian & Non-reflexive adopter & no \\
\hline Cynthia & Straight & 34 & White & White & Non-reflexive adopter & no \\
\hline Frances & Same-sex & 47 & White & White & Non-reflexive adopter & no \\
\hline Ann & Same-sex & 23 & White & White & Non-reflexive adopter & no \\
\hline Joyce & Same-sex & 32 & White & White & Non-reflexive adopter & no \\
\hline Denise & Same-sex & 43 & White & White & Non-reflexive adopter & no \\
\hline Elizabeth & Straight & 37 & White & White & Acquiescent adopter & no \\
\hline Carol & Straight & 26 & White & White & Acquiescent adopter & no \\
\hline Helen & Straight & 33 & White & White & Acquiescent adopter & no \\
\hline Patricia & Straight & 27 & White & White & Acquiescent adopter & no \\
\hline Alice & Straight & 40 & White & White & Acquiescent adopter & yes \\
\hline Shirley & Straight & 27 & White & White & Acquiescent adopter & no \\
\hline Cheryl & Same-sex & 34 & White & White & Same-sex resister & yes \\
\hline Diane & Same-sex & 31 & White & White & Same-sex resister & no \\
\hline Heather & Same-sex & 55 & White & White & Same-sex resister & no \\
\hline Doris & Same-sex & 27 & White & White & Same-sex resister & no \\
\hline Evelyn & Same-sex & 31 & White & White & Same-sex resister & no \\
\hline Judith & Same-sex & 35 & Black & Mixed race & Same-sex resister & no \\
\hline Rose & Same-sex & 43 & White & White & Same-sex resister & no \\
\hline Janice & Same-sex & 42 & White & White & Same-sex resister & yes \\
\hline Catherine & Same-sex & 41 & White & White & Same-sex and frugal resister & yes \\
\hline Julie & Same-sex & 43 & White & White & Same-sex and frugal resister & no \\
\hline Jean & Same-sex & 44 & White & White & Same-sex and frugal resister & no \\
\hline Carolyn & Same-sex & 37 & White & White & Same-sex and frugal resister & yes \\
\hline Kelly & Same-sex & 36 & White & White & Same-sex and frugal resister & no \\
\hline Nicole & Same-sex & 39 & White & White & Same-sex and frugal resister & yes \\
\hline Lisa & Straight & 38 & Black & White & Frugal resister & no \\
\hline Karen & Straight & 35 & White & Latino & Frugal resister & no \\
\hline Sandra & Straight & 24 & White & White & Frugal resister & no \\
\hline Donna & Straight & 51 & White & White & Frugal resister & no \\
\hline Ruth & Straight & 41 & White & Mixed race & Frugal resister & no \\
\hline Sharon & Straight & 34 & White & Latino & Frugal resister & no \\
\hline Kimberly & Straight & 47 & Black & Black & Frugal resister & no \\
\hline
\end{tabular}




\begin{tabular}{lllllll} 
Pseudonym & $\begin{array}{c}\text { Marriage } \\
\text { type }\end{array}$ & Age & $\begin{array}{c}\text { Participant's } \\
\text { race/ethnicity }\end{array}$ & $\begin{array}{c}\text { Spouse's } \\
\text { race/ethnicity }\end{array}$ & \multicolumn{1}{c}{$\begin{array}{c}\text { Analytic Group } \\
\text { marriage? }\end{array}$} \\
\hline Deborah & Straight & 35 & Latina & White & Frugal resister & no \\
Alicia & Same-sex & 40 & Latina & Latina & Frugal resister & no \\
Margaret & Straight & 24 & White & Indian & Other & no \\
Sarah & Straight & 51 & White & Black & Other & no
\end{tabular}


Tina Fetner is an associate professor in sociology at McMaster University. She is the author of How the Religious Right Shaped Lesbian and Gay Activism. Her research has been published in Social Problems, Public Opinion Quarterly, American Journal of Political Science, and the Canadian Review of Sociology.

Melanie Health is an associate professor in sociology at McMaster University. She is the author of One Marriage under God: The Campaign to Promote Marriage in America. She has published in Gender \& Society, The Sociology Quarterly, Qualitative Sociology, and Contexts. 